\title{
Technological achievement in the food industry in Malaysia
}

\author{
*Rahmat, S., Chew, B.C. and Abdul Hamid, M.S.R. \\ Faculty of Technology Management and Technopreneurship, Technology Campus, University Technical \\ Malaysia Melaka, Hang Tuah Jaya, 76100 Melaka, Malaysia
}

\begin{abstract}
Article history:
Received: 5 February 2021

Received in revised form: 26

March 2021

Accepted: 29 May 2021

Available Online: 21

November 2021

\section{Keywords:}

Food sustainability,

Sustainability practices,

Economic planning unit,

Food technology,

Malaysia
\end{abstract}

\section{DOI:}

https://doi.org/10.26656/fr.2017.6(1).091

\begin{abstract}
Issues pertaining to food sustainability have long been debated in developing countries. Food sustainability practices benefit the environment, societies and economies, yet in Malaysia food production and management are still lagging in sustainability practices. The food industry needs to explore new methods in food production because of population increase, peoples' lifestyle, demand for healthy foods, and environmental concerns. For this reason, this review paper discussed technological achievements in the food industry to help food producers improve production. It is crucial for Malaysia to ensure sustainability in food production technology in the 12th Economic Planning Unit (EPU) projection for 2021-2025. The EPU aims to restructure and empower the existing industry. This paper discussed the food technology sub-sector focusing on agriculture and livestock in Malaysia. This focus hopes to boost existing government strategies and improve food producers' business performance following the EPU. Here, this paper highlights the government's involvement in technology application to help farmers' access affordable technology via research assistance from the government.
\end{abstract}

\section{Introduction}

Malaysia has gradually developed and improved its agriculture and food processing industries to become a net exporter of processed food. At present, the main contributors to the agricultural sub-sectors in Malaysia are poultry and paddy. Both produce are going through innovative research and development and modernisation initiatives to be transformed into high-income and sustainable industries (Malaysian Investment Development Authority, 2019). In advancing sustainability in the food processing technology, the usage of local raw materials has increased along with larger product diversification and higher investment to improve capacity in the industry. Although the food manufacturing sector in Malaysia is a critical industrial area, there is no suitable sustainability assessment method to measure food manufacturing activities (Ahmad et al., 2017).

Meanwhile, the livestock industry in Malaysia hasn't changed much. Current livestock data shows that Malaysia is experiencing shortages in fresh beef production, with higher consumer demand (Sahar and Chamhuri, 2016; Mohammad Nor et al., 2018). The reason behind this is that the livestock sector (for beef) remains uncommercialised due to low productivity. Furthermore, the private sector is inactive in this matter (beef sub-sector) and shows no interest to invest in this industry. As a result, the industry only supplies between 28 and 30\% of domestic demand (Mohammad Nor et al., 2018). Similarly, local milk production only supplies less than $10 \%$ of domestic demand. This is due to low productivity and poor technology adoption. Meanwhile, rice production in Malaysia has reached about $75 \%$ selfsufficiency level (SSL) and adequately serves 60 to $65 \%$ for domestic use (Rahim et al., 2017).

Moving to sustainability practices in food production, Olesen et al. (2000), Power et al. (2012), Shen et al. (2013) and Evans and Syed (2015) urged that innovation and appropriate cost-effective technology, capable to improve sustainable livestock including reducing crop loss, distribution network, market information, green innovation be implemented (Frazer, 2008). The development of costefficient technology development can improve energy usage whilst sustaining the manufacturing, transportation, and other economic sectors that gives significant environmental impact (Tilman et al., 2002). In other words, using sustainable technology minimises the use of natural resources, minimises wastage, saves 
energy and improve operational and organisational procedures. However, Frazer (2008) claimed that the main constraints in adopting livestock technology are the availability of capital and technological know-how. In terms of availability of capital, while many large, highlycapitalised commercial farms are benefiting from technological advancements, poor smallholder farmers are often constrained due to high equipment costs and little access to training or follow-up resources for widescale adoption (Power et al., 2012). Nonetheless, this trend is starting to change as the private and government sectors show concern by investing more in technology solutions. This is achieved by introducing affordable technology and equipment in remote areas that are ecologically sustainable and rendering support and follow-up to farmers using them.

In terms of technological know-how, it can be developed through good knowledge (Pacholewicz et al., 2016), which refers to labour efficiency (Ezeh et al., 2012; Makutènienė and Baležentis, 2015). Food producers, non-government organisations and government agencies demand integration of knowledge from different disciplines (Dicks et al., 2013). Technological innovation is not only critical for on-farm use, at the same time, but it also supports financial transactions, health care, and improved educational access efficiently. In this context, this review paper discusses cost-effective farming technologies. The information is from secondary data (media, articles, and official government agencies). The scope of this paper focused on livestock and paddy production.

\section{Cost-effective technology}

The emergence of technology has forced the food sector to assess both food production and services. The challenges in making this sector sustainable remain an ongoing struggle. Dardak and Adham (2020) suggested several measures to accelerate the adoption of farming technologies namely by preserving and optimising the use of agricultural land and intensifying research, development and commercial (R\&D\&C) in priority areas to improve productivity and income of farmers, fishermen, and smallholders. Adopting technology in farming helps to accelerate the production process and promoting comprehensive monitoring of production.

In adopting farming technologies, most government involvements are through collaborations with other agencies. For paddy production, the Department of Agriculture (DOA) collaborates with Malaysia Remote Sensing Agency by introducing an application for rice mapping and monitoring using GIS and satellite imagery. It is used to map the geographical information of paddy parcels and monitor and observe the activities during the growth stage (Sahak and Sutha, 2014). Another form of collaboration is to encourage farmers to use green fertiliser technology (GFT) to increase paddy production while sustaining the environment in good condition (Adnan et al., 2017).

In terms of improving research, development, and commercial (R\&D\&C), it is the belief that government interventions are needed as it requires extensive investments (Sahar and Chamhuri, 2016). R\&D\&C activities support the green initiative by promoting green technology in Malaysia such as through the green-blue packaging programme (SIRIM, 2017). Such programmes present new prospects to new manufacturers to meet consumer demand for cost-effective, environmentally friendly food with attractive retail packaging options and contributing to long-term business sustainability. Another technology research area discussed is the use of tractors with an autopilot-automated steering system that performs better by saving operators' energy expenditure and improving the field capacity of operation. Tractors with autopilot-automated steering are useful in agricultural operations even though it is still new in Malaysia (Azmi et al., 2020). While for poultry production, Mohd Yusof et al. (2019) mentioned that the use of biogas technology can benefit livestock waste management. The use of biogas technology can minimise environmental pollution, help poultry farms reduce electricity costs, and farmers can profit by using biogas for cooking and to generate electricity. However, the use of biogas technology in the livestock sector is still low compared to other agriculture sectors due to many factors. Abdeshahian et al. (2016) stated that there are on -going researches on the use of biogas from organic waste from farm animals and slaughterhouse to generate electricity. The government can play a role by providing guaranteed refunds to farmers who use the biogas system in their farms (even on a small scale). Additionally, expansion of the biogas programme can be further encouraged by introducing and promoting standard structures and rules for biogas plants, as a rule. The availability of technical experts in biogas systems is also critical to the success of biogas in Malaysia in the future (Mohd Yusof et al., 2019).

Nevertheless, there is a simple technology application that farmers can implement. Ali and Man (2016) related that by using smartphones farmers can update their farming progress or establish a community farming group to exchange information using farmer friendly software. Yun (2020) reported on the collaboration between IBM and Sarawak Multimedia Authority (SMA) to support small farmers by introducing smart farming technologies by providing training, education and grants for farmers to adopt the 
technology. Smart farming technology can be used to collect weather data, land topography, and information about soil health using the Internet of Things (IoT). Smart technologies ease farming decisions like the best times for planting, ploughing, spraying or harvesting. It also encourages the younger generation to become interested in agriculture and farming. Dardak et al. (2020) mentioned that the increased number of graduates in agro-technopreneurs can be encouraged to invest in R\&D through introducing new technologies, new products and services. Jaabi (2017) reported that having modern high-tech farms, permanent food parks, establishing learning institutions for modern farming and forming agriculture outsourcing service (AOS) organisations can attract youth involvement in agriculture. Meanwhile, FGV Holdings Berhad (2021) is offering a technology solution platform to encourage young people to venture into the plantation sector. The three areas of technology solution being offered are supply chain technology and logistics, estate management and mills and bulking automation. The technology solutions are capable to reduce carbon and lower energy consumption. Thus far, there is no data to show how many agriculture business owners have applied for it.

However, Adnan et al. (2017) reported that Malaysian farmers are not yet ready to adopt farming technology, especially when dealing with innovation technology. Mohammad Nor et al. (2018) added that to ensure that agriculture products meet the demand for food adequately; farmers should become more knowledgeable about innovation and technology. There is a need for a platform to discuss technology transfer involving farmers to increase their awareness of the compatibility of the technology before transfer. In other words, the recipients (farmers) must have similar knowledge that can help them understand the technology and knowledge (Dardak and Adham, 2020).

\section{Conflict of interest}

The authors declare no conflict of interest.

\section{Acknowledgements}

This research was funded under the Fundamental Research Grant Scheme number F00182 by the Ministry of Education. This study is part of a dissertation that was submitted as partial fulfilment to meet requirements for the degree of Doctor of Philosophy at Universiti Teknikal Malaysia Melaka.

\section{References}

Abdeshahian, P., Lim, J.S., Ho, W.S., Hashim, H. and
Lee, C.T. (2016). Potential of biogas production from farm animal waste in Malaysia. Renewable and Sustainable Energy Reviews, 60, 714-723. https:// doi.org/10.1016/j.rser.2016.01.117

Adnan, N., Md Nordin, S., Rahman, I. and Noor, A. (2017). Adoption of green fertilizer technology among paddy farmers: A possible solution for Malaysian food security. Land Use Policy, 63, 3852. https://doi.org/10.1016/j.landusepol.2017.01.022

Ahmad, S., Wong, K.Y. and Elahi, H. (2017). Sustainability Assessment and Analysis of Malaysian Food Manufacturing Sector - A Move Towards Sustainable Development. Advanced Science Letters, 23(9), 8942-8946. https:// doi.org/10.1166/asl.2017.10000

Ali, M. and Man, N. (2016). Tech help for better farming. The Star. Retrieved on January 31, 2021 from https://www.thestar.com.my/opinion/ letters/2016/03/31/tech-help-for-better-farming

Azmi, M., Mohammad, R. and Pebrian, D. (2020). Evaluation of soil EC mapping driven by manual and autopilot - automated steering systems of tractor on oil palm plantation terrain. Food Research, 4 (Supplementary 5), 62-69. https://doi.org/https:// doi.org/10.26656/fr.2017.4(S5).015

Dardak, R.A. and Adham, K.A. (2020). New Model of Agrobased Technology Transfer from Government Research Institutions to Private Firms in Malaysia. FFTC Agricultural Policy Platform. Retrieved on January 31, 2021 from https://ap.fftc.org.tw/system/ files/field/file/article/-A new model of agrobased technology transfer in Malaysia_.pdf

Dardak, R., Nik, R. and Haimid, T. (2020). Youth and Agro technopreneurship ecosystem in Malaysia. FFTC Agricultural Policy. Retrieved from https:// ap.fftc.org.tw/article/2580

Dicks, L.V., Bardgett, R.D., Bell, J., Benton, T.G., Booth, A., Bouwman, J. and Sutherland, W.J. (2013). What do we need to know to enhance the environmental sustainability of agricultural production? A prioritisation of knowledge needs for the UK food system. Sustainability, 5(7), 30953115. https://doi.org/10.3390/su5073095

Evans, A. and Syed, S. (2015). From niche to mainstream - Halal Goes Global. International Trade Centre. Geneva: International Trade Centre 2015. Retrieved on January 22, 2018 from http:// search.proquest.com.ezaccess.library.uitm.edu.my/ docview $/ 224324915$ ?accountid $=42518$

Ezeh, C.I., Anyiro, C.O. and Chukwu, J.A. (2012). Technical Efficiency in Poultry Broiler Production in Umuahia Capital Territory of Abia State, Nigeria. 
Greener Journal of Agricultural Sciences, 2(1), 1-7. https://doi.org/10.15580/GJAS.2013.3.1206

FGV Holdings Berhad. (2021). Our services- plantation business solutions. Retrieved on January 30, 2021 from http://fgvprodata.com.my/?page_id=39

Frazer, L. (2008). Green Screen for Poultry Farms. Environmental Health Perspective. Environews, 116 (11), A477-A477. https://doi.org/10.1289/ehp.116a477

Jaabi, A. (2017). Smart Farming Is The Way To Go. Retrieved March 24, 2021, from https:// www.isis.org.my/2017/09/18/smart-farming-is-theway-to-go/

Mohd Yusof, N.A., Suhaimi, D., Nurshuhada, S. and Roslan, M.Y. (2019). Overview on the development of biogas technology in livestock sector in Malaysia. Malaysian Journal of Veterinary Research, 10(2), 93 $-99$.

Makutėnienè, D. and Baležentis, T. (2015). The trends of technical, environmental and resource efficiency across agricultural sectors of european countries. Management Theory and Studies for Rural Business and Infrastructure Development, 37(2), 241-251. https://doi.org/10.15544/mts.2015.22

Malaysian Investment Development Authority. (2019). Food Industry in Malaysia. Malaysian Investment Development Authority (MIDA). Retrieved on September 25, 2020 from http://www.mida.gov.my/ home/administrator/system_files/modules/photo/ uploads/20180903103354_Food Industry 2018_V4.pdf

Mohammad Nor, N.A.A., Rosali, M.H., Mohd Syauqi, N., Zainol Abidin, A.Z. and Sulaiman, N.H. (2018). Adoption of Technology in Malaysia' s Livestock Industry. FFTC Agricultural Policy Platform. Retrieved on January 31, 2020 from http:// ap.fftc.agnet.org/ap_db.php?id $=946$

Olesen, I., Groen, A.F. and Gjerde, B. (2000). Definition of animal breeding goals for sustainable production systems. Journal of Animal Science, 78(3), 570-582. https://doi.org//2000.783570x

Pacholewicz, E., Sura Barus, S.A., Swart, A., Havelaar, A.H., Lipman, L.J.A. and Luning, P.A. (2016). Influence of food handlers' compliance with procedures of poultry carcasses contamination: A case study concerning evisceration in broiler slaughterhouses. Food Control, 68(August), 367378. https://doi.org/10.1016/j.foodcont.2016.04.009

Power, G., Gardaz, A. and Dey, J. (2012). Scaling upGlobal Food Security and Sustainable Agriculture. New York, USA: United Nations Global Compact.

Rahim, F.H.A., Hawari, N.N. and Abidin, N.Z. (2017).
Supply and demand of rice in Malaysia: A system dynamics approach. International Journal of Supply Chain Management, 6(4), 234-240.

Sahak, P. and Sutha V. (August). GIS for Rice Field Management. Retrieved from Geospatial World website: January 29, 2021 from https:// www.geospatialworld.net/article/gis-for-rice-fieldmanagement/

Sahar, N. and Chamhuri, N. (2016). Agricultural policies effect on livestock industry - perspectives from Malaysia and New Zealand. International Journal of Agriculture, Forestry and Plantation, 2, 77-83.

Shen, J., Cui, Z., Miao, Y., Mi, G., Zhang, H., Fan, M. and Zhang, F. (2013). Transforming agriculture in China: From solely high yield to both high yield and high resource use efficiency. Global Food Security, 2(1), 1-8. https://doi.org/10.1016/j.gfs.2012.12.004

SIRIM. (2017). Green-Blue Packaging Programme. Retrieved on January 22,2018 from SIRIM website: http://www.sirim.my/index.php/76-core-business/ commercialisation-technical-services/458- greenblue-packaging-programme

Tilman, D., Cassman, K.G., Matson, P.A., Naylor, R. and Polasky, S. (2002). Agriculture sustainability and intensive production practices. Nature, 418, 671 -677. https://doi.org/10.1038/nature01014

Yun, T. Z. (2020). Agritech: Smart agriculture for smallholders. Retrieved on November 2, 2020 from The Edge Markets website: https:// www.theedgemarkets.com/article/agritech-smartagriculture-smallholders 